DOI: $10.2478 / \mathrm{v} 10025-012-0010-3$

JOURNAL OF WATER

AND LAND DEVELOPMENT

J. Water Land Dev. No. 15, 2011: 99-113

\title{
The role of grasslands in the formation of structural and spatial order of rural areas
}

\author{
Stanisław TWARDY1), Halina JANKOWSKA-HUFLEJT ${ }^{2)}$, \\ Barbara WRÓBEL ${ }^{2}$
}

\footnotetext{
1) Institute of Technology and Life Sciences in Falenty, Małopolska Research Centre in Kraków, ul. Ułanów 21B, 31-450 Kraków, Poland, phone/fax +48 12 412-84-59, e-mail: itepkrak@itep.edu.pl ${ }^{2)}$ Institute of Technology and Life Sciences in Falenty, Department of Grassland, al. Hrabska 3, 05090 Raszyn, Poland, phone +48 720-05-98
}

\begin{abstract}
This paper presents structural changes witch took place in Poland as a result of social and economic transformation. In relation to 1970' and 1980' it was certify that agricultural lands were significantly decreased (to 16.15 million ha in 2008). Within them arable lands were reduced in favour of grasslands and other lands which are markedly noticed in Carpathian areas. Actually use of grasslands in those areas transcends 40 per cent with regard to whole area, however above $700 \mathrm{~m}$ a.s.l. contribution of grasslands pass 65 per cent. Yields of grass biomass from those grasslands were also decreased.
\end{abstract}

Key words: permanent grasslands, structural changes, mountain rural areas

\section{INTRODUCTION}

Land use structure has not changed much in the last years. Till the end of the 1980 'it was stable with respect to all types of land use. Agricultural lands occupied c. $61 \%$ out of 312.7 thousand $\mathrm{km}^{2}$ of the country area, forests grew on c. $28 \%$ of the area and other grounds covered c. $11 \%$.

Agricultural lands were treated in those days almost exclusively as productive grounds whose undisturbed functioning was guaranteed by proper agrotechnology, particularly by the increasing rate of mineral fertilisation. Mineral fertilisers were relatively cheap and strongly promoted by the state authorities. The main aim was to achieve as much plant and animal production as possible regardless of circumstances and consequences. On the other hand, organic fertilisers, mainly those from animal production, were considered less useful and troublesome by-product due to their large volume and mass and to inconvenient technology of their storage and spreading over agricultural lands. They were used reluctantly 
since their application was associated with additional inputs to labour power, fuel and machines.

Such an approach, often worsened by organizational errors and enforced collectivization, resulted in gradual impoverishment and degradation of rural areas. Any agricultural productive activity, regardless of its costs, was overestimated in those days compared with other aspects, particularly with hardly parameterized environmental values. This in turn brought about, different in various regions of the country, specific decomposition of desired equilibrium between the natural environment and living and working conditions and recreation (GUZIK, 1995; TWARDY, 1993).

Now, many of such areas undergo a characteristic structural and spatial reform. The reform aims at restoring basic functions to rural areas through the implementation of the principles of sustainable development. At the current state of country development this is associated with the combination of moderately intensive economic activity with environmental protection, mainly pertaining to water and soil habitats.

In general, this process proceeds differently in lowland areas and in uplands and mountains in the south of our country. Therefore, description of the changes mentioned above is presented here generally for the whole country but more specifically for the Carpathian region. Such selection is justified by the fact, that the Carpathians are a huge mountain range joining many countries and in many natural aspects are similar to alpine regions

In every case, however, grasslands played an important role in the formation of new structural, spatial and productive conditions irrespective of the physico-geographic region. The importance of grasslands demonstrated itself regardless of the way and intensity of management and positive properties were observed even if the sward was not used at all. Under conditions of sustainable development and implementation of environmental friendly economy, the same attention is paid to biomass production and to stabilisation and protection of soil profile.

\section{SPATIAL TRANSFORMATION IN POLAND}

Changes of land use structure in our country presented in figure 1 cover a period of 34 years (1974-2008) from both before and after system transformation. The former pertains to the years 1970' and 1980' and the latter - to the years 1990' and part of the first decade of the $21^{\text {st }}$ century.

Presented graph shows that significant changes in the land use structure took place in the last decade of the 20th century due to a deep social and economic transformation. The changes largely concerned agricultural lands whose area markedly decreased from 18.94 million ha (61.6\% of the country area) in 1974 to 16.15 million ha $(51.7 \%)$ in 2008 . The reduction of 2.8 million ha of agricultural lands in 
the study period equals to mean annual decrease by 82 thousand ha and in the period after system transformation this annual decrease exceeded 120 thousand ha. At the same time the share of other land use forms (settlements, communications, barren lands etc.) gradually increased.

Percentage share of forests increased from 27.4 to $29.6 \%$ in the study area and that of other grounds including barren lands from 11.0 to $18.7 \%$ between 1974 and 2008. Analysis of land use changes in our country clearly shows that large part of agricultural lands was seized for building and broadly understood infrastructure and consequently moved to the category "other grounds".

1974

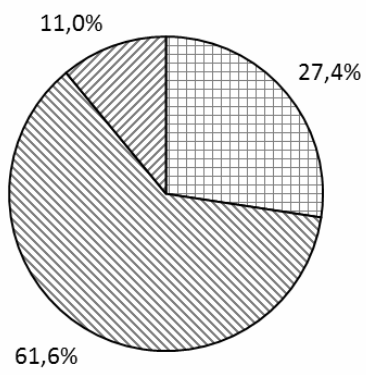

1995

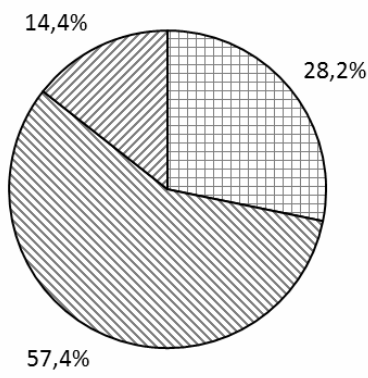

1984

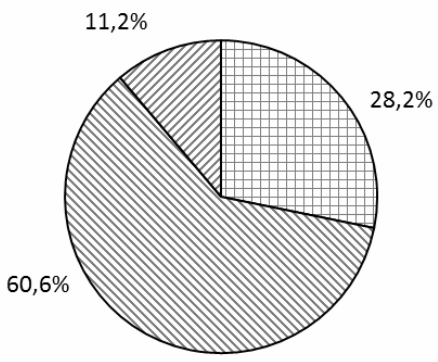

2008

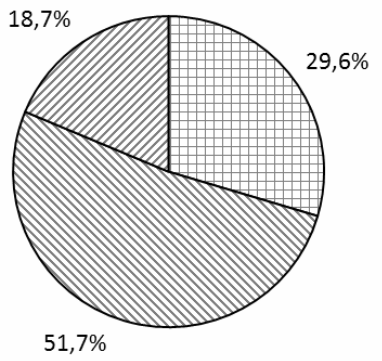

$\boxplus$ forests $\quad$ agriculture lands $\square$ other grounds and baren lands

Fig. 1. Changes (in \%) of the land use in Poland in the years 1974-2008

Due to structural changes presented in Fig. 1, the area per one inhabitant of the country gradually decreased. Structural changes were more responsible for the decrease than population growth which is illustrated in Fig. 2.

There was 0.92 ha of the country area and 0.58 ha of agricultural lands per 1 Polish citizen in 1974. In 2008 the respective figures were 0.82 and 0.48 . In the case of agricultural lands, the so-called "per capita feeding area" is slightly smaller and equals 0.43 ha (Rolnictwo..., 2005). The reduction of the per capita surface 


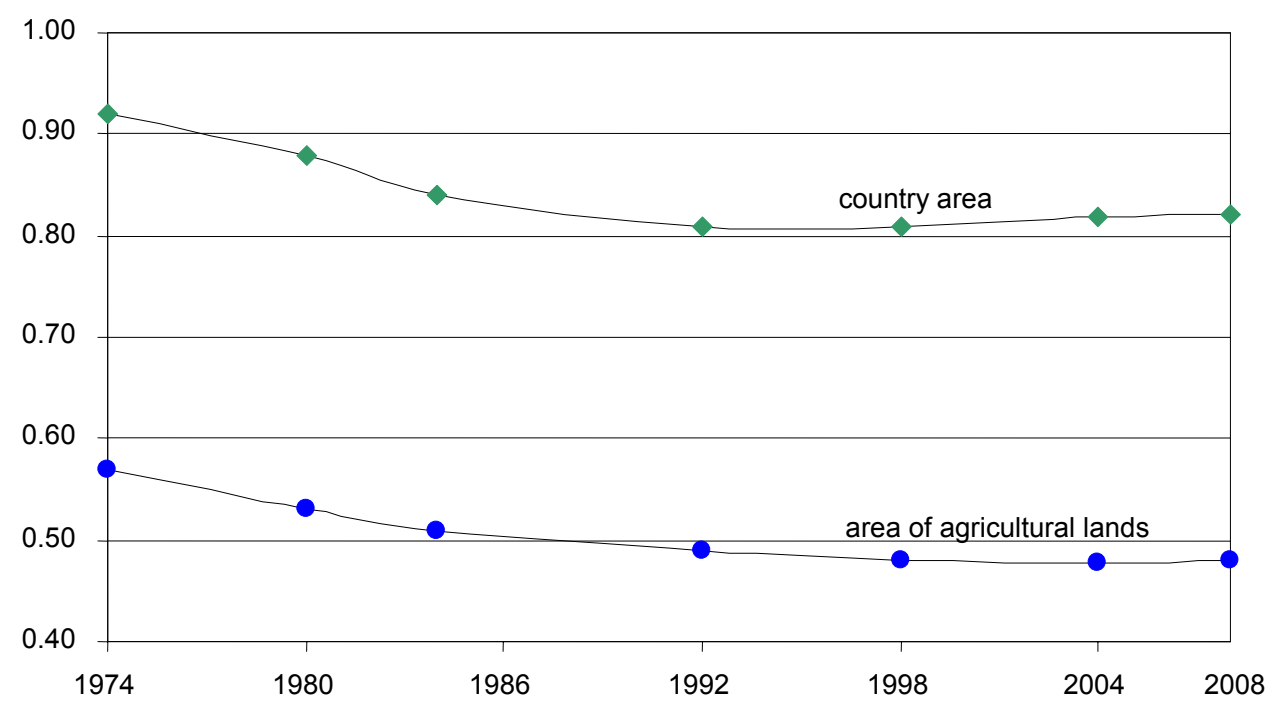

Fig. 2. Area (in ha) per 1 Poland's inhabitant

area taking place recently has been moderated by zero or even negative population growth rate. Moreover, some inconsistencies in given surface areas result from migrations of Polish citizens over Europe. Therefore, one may only approximately assume that the changes have been insignificant with respect to both agricultural lands and total surface area since the beginning of the last decade of the $20^{\text {th }}$ century (Fig. 2).

Comparison of the agricultural land use structure from before system transformation (data from 1974 and 1984) with that of later years (1995 and 2008) shows (Fig. 3) that, despite substantial general reduction, proportions between different types of agriculture remained nearly the same. Since the 1970' and even earlier, the structure of agricultural lands was static with respect to all forms of agricultural land use in the country. Arable lands dominated in this structures occupying 74.9-77.4\% of lands (Fig. 3).

Meadows occupied $12.7-15.2 \%$, pastures $-4.5-8.5 \%$ and orchards $-1.4-2 \%$. Noteworthy, the percent data refer to different areas of agricultural lands. Hence, almost identical percentage share of arable grounds was noted e.g. for the years $1984(77.0 \%)$ and $1995(77.4 \%)$ but in fact they were clearly different areas (Fig. 3). In this particular case, they equalled 14.83 and 13.88 million ha, respectively. Large areas of barren lands exceeding 0.5 million ha have been noted recently. According to earlier statistical reports, these areas were included into other categories of grounds like e.g. settlements, communication grounds, mines etc. 

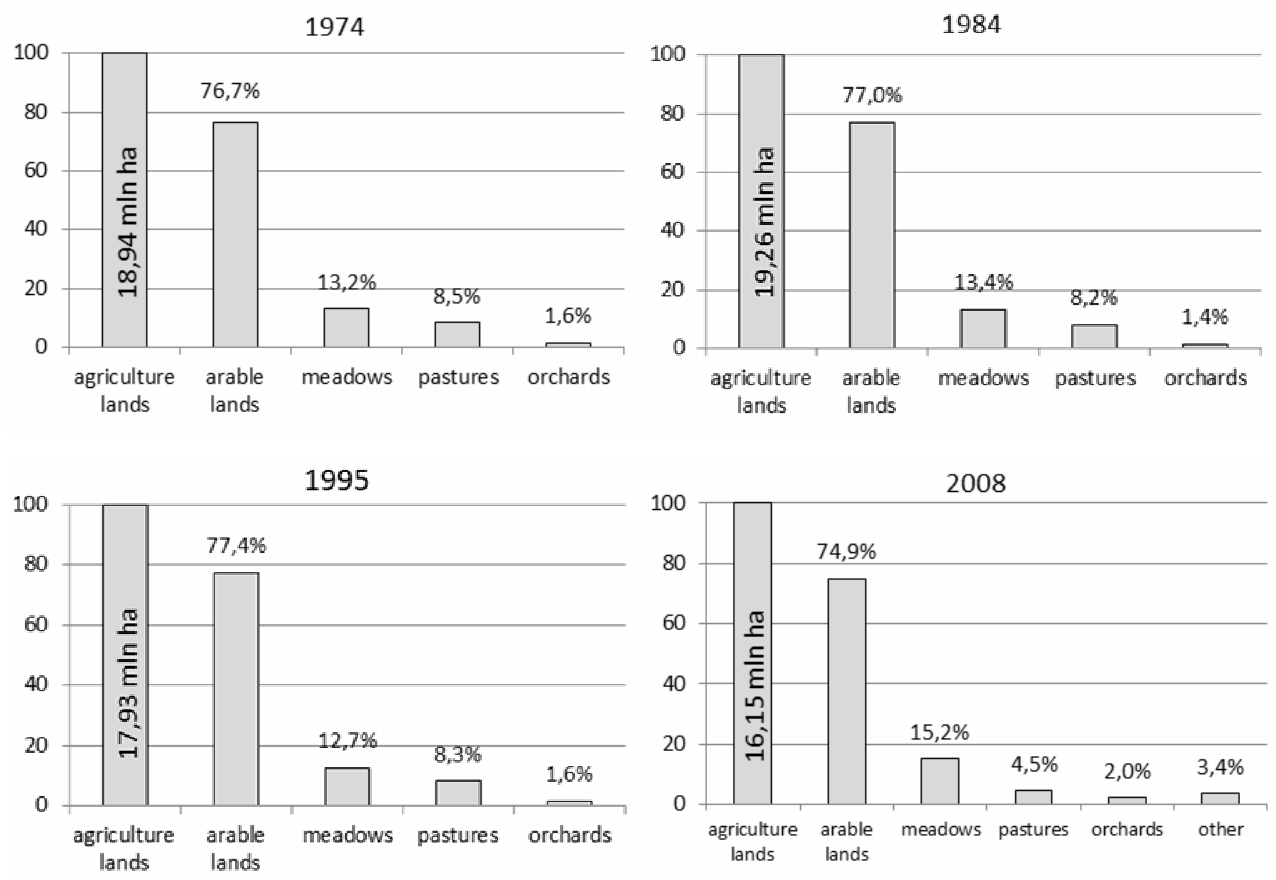

Fig. 3. Changes in the structure of agricultural lands (\%) in the years 1974-2008

\section{STRUCTURAL TRANSFORMATION OF THE CARPATHIAN AREAS}

Mountain areas occupy c. 27 thousand $\mathrm{km}^{2}$ in Poland i.e. more than $8.7 \%$ of the country area. They are composed of three separate ranges: the Carpathians, the Sudetes and the Holy Cross Mountains. The Carpathians are largest and form a 300 $\mathrm{km}$ long and 60-70 km wide belt along the southern border of our country. Total surface area of Polish Carpathians is 19.6 thousand $\mathrm{km}^{2}$ (JAGLA et al., 1981). Their height increases southward from the lowest Carpathian Uplands through the Beskidy and Bieszczady of medium height to alpine range of the Podhale and Tatras. A characteristic feature of these areas, particularly those at higher elevation, is a large share of permanent, both grassy and forest, plant cover. Permanent grasslands are the main food base for ruminants, mainly cattle and sheep, bred there.

The Carpathians were formed by various geological factors decisive for their structure, orography and relief and by natural, including climatic, factors. Their economic use, however, clearly depends on the altitude a.s.l. Climatic and soil characteristics change with altitude which has a direct effect on habitat conditions. Combined, these factors determine the way of land use for agricultural and forestry purposes. Other climatic factors like solar insolation, cloudiness, evaporation, wind speed or the length of snow period and the thickness of snow cover change respec- 
tively. Under such conditions plant cover displays a bioclimatic zonation (OBRĘBSKA-STARKLOWA et al., 1995) and decreasing soil quality determines the possibility of growing many plant crops.

Described relationships manifest themselves in quantitative changes of plant biomass produced in a given habitat conditions and in qualitative changes associated mainly with floristic diversity. Climatic conditions translate also to the length of the vegetation period which shortens by 8 to 10 days per every $100 \mathrm{~m}$ of the altitude a.s.l. (KOSTUCH, 1976).

Grasslands are affected by the variability of habitat factors to a smallest extent which favours them in comparison with other crop plants. Moreover, grasses form a sward layer and thus provide protection and stabilisation of the soil profile even at high inclinations of mountain slopes. The use of grasslands and forest ecosystems for structural and habitat stabilisation of a given area is of primary importance for spatial management. Man decides upon the place, way and intensity of land use. Human activity may protect the space against degrading exploitation or, on the contrary, may excessively and wastefully exploit it.

System transformation combined with market agricultural economy and more friendly approach to highlands was followed by immense structural changes in the Carpathian areas (GŁĘBOCKI, 2006; TWARDY, 2009). Their range in the years 1988-2004 is presented in Table 1.

Table 1. Changes in the structure of agricultural lands of the Carpathian areas (in \%)

\begin{tabular}{c|c|c|c|c|c|c}
\hline \multirow{2}{*}{$\begin{array}{c}\text { Altitude } \\
\text { m a.s.1. }\end{array}$} & \multicolumn{7}{|c|}{ Percentage share of area } \\
\cline { 2 - 7 } & \multicolumn{2}{|c|}{ arable lands } & \multicolumn{2}{c}{ grasslands } & \multicolumn{2}{c}{$\begin{array}{c}\text { other } \\
\text { (including barren lands) }\end{array}$} \\
\cline { 2 - 7 } & $1988-1991$ & $2002-2004$ & $1988-1991$ & $2002-2004$ & $1988-1991$ & $2002-2004$ \\
\hline $300-500$ & 68.6 & 47.4 & 18.5 & 30.2 & 12.9 & 22.4 \\
$500-700$ & 52.3 & 30.3 & 30.6 & 50.2 & 17.1 & 19.5 \\
$700-900$ & 48.5 & 16.3 & 38.6 & 65.4 & 12.9 & 18.3 \\
$900-1100$ & 22.7 & 5.6 & 55.7 & 68.7 & 21.6 & 25.7 \\
$>1100$ & - & - & 43.0 & 44.6 & 57.0 & 55.4 \\
Total & 62.3 & 37.4 & 23.1 & 40.1 & 14.6 & 22.5 \\
\hline
\end{tabular}

Arable lands decreased their share by c. $40 \%$ in the structure of agricultural lands of Polish Carpathians and grasslands increased their share by more than $70 \%$ compared with the situation from before system transformation. The share of other grounds, including barren lands, increased by more than 50\%. In particular zones the changes were even deeper as seen in Table 1.

Arable lands markedly decrease their share with increasing altitude a.s.l. in favour of grasslands. Hence, at altitudes higher than $700 \mathrm{~m}$ a.s.l. the former occupy only $5-16 \%$ and grasslands $-65-70 \%$ of the total agricultural areas. One should, 
however, keep in mind that barren mountain lands include large areas covered with sward which could be considered extensively used pastures. With such correction, the total share of grasslands above $700 \mathrm{~m}$ increases to $80-85 \%$.

Of course, grasslands are understood here as areas permanently overgrown by grass vegetation which may also play non-productive functions. Variability of their yielding in analysed years and in relation to altitude is presented in Fig. 4. Results are comparatively summarised from earlier studies carried out in the described period of time (TWARDY, 1993; 2006; 2008; 2009). They were recalculated for hay irrespective of the way of grassland utilisation and yield variability was related to the yield obtained at the foot of the Carpathians (altitude 250-300 m a.s.1.)

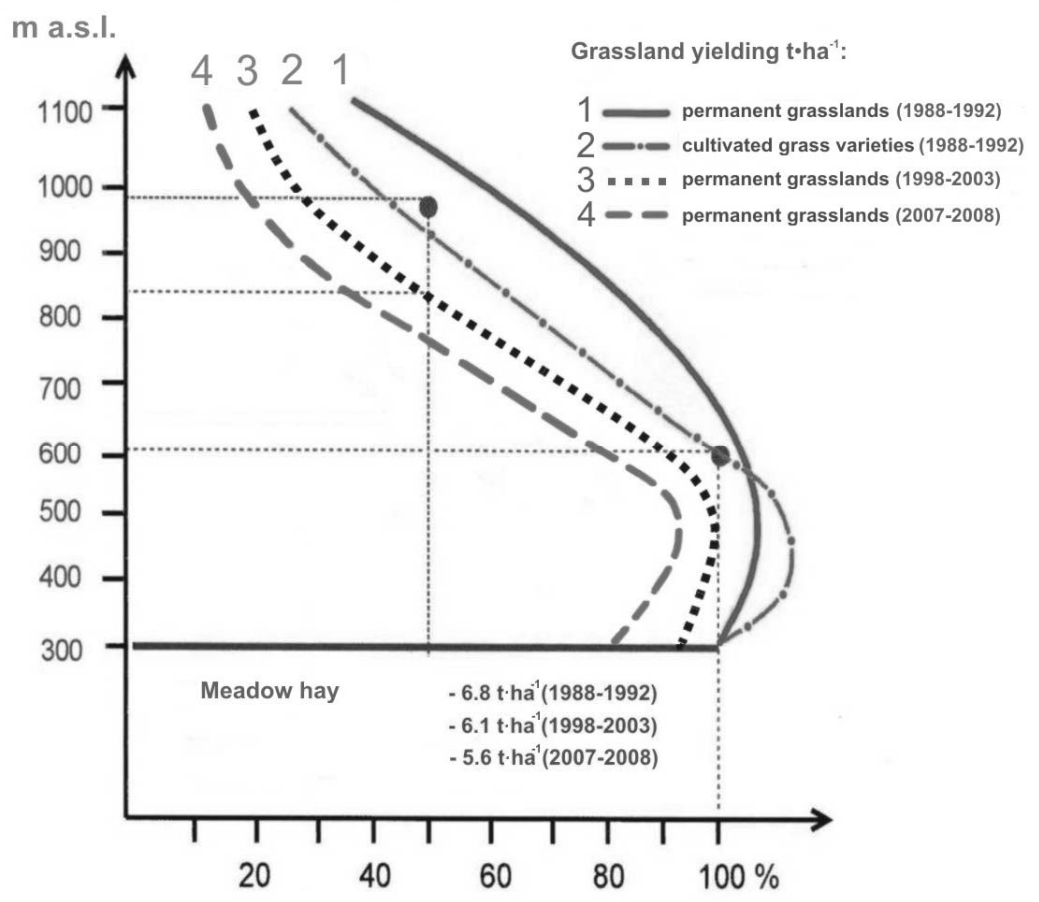

Fig. 4. Variability of grassland yielding in relation to altitude a.s.l.

Presented curves of the variability in biomass production demonstrate that the highest yields (1) were obtained in the period when the main focus was on achieving maximum productive effects (till the beginning of the last decade of the $20^{\text {th }}$ century). In those days mean hay yield obtained at the foot of the Carpathians was $6.9 \mathrm{t} \cdot \mathrm{ha}^{-1}$ and that at an elevation of $400-500 \mathrm{~m}$ a.s.l. was even higher $-7.0 \mathrm{t} \cdot \mathrm{ha}^{-1}$. Similar yields were noted in new grasslands sown with seeds from specialised seed plantations. At higher elevations, however, these crops suffered $10-15 \%$ losses 
compared with the yields obtained from permanent grasslands. The losses were usually caused by neglecting agro-technical regimes and mainly by insufficient fertilisation and delayed mowing and harvesting.

In subsequent years (1998-2003) the yielding of permanent grasslands in the Polish Carpathians was markedly lower (3) both at the lowest elevations $\left(6.1 \mathrm{t} \cdot \mathrm{ha}^{-1}\right)$ and at all higher altitudes. The reason of this was in definitely smaller interest of farmers in fodder production due to parallel reduction of farm animals, mainly ruminants (GŁĘBOCKI, 2006). Fodder quality, not discussed here in details, also decreased due to the appearance of large amounts of less valuable plants and weeds. This situation persisted for nearly the whole first decade of the $21^{\text {st }}$ century illustrated by curve (4) which refers to the years 2007-2008 in Fig. 4.

Observations show that such a status has remained until now; in lower parts of the Carpathian areas (300-600 m a.s.l.) hay yields range from 5.5 to $6.0 \mathrm{t} \cdot \mathrm{ha}^{-1}$ and at $800-900 \mathrm{~m}$ a.s.1. they vary between 2.5 and $3.0 \mathrm{t}^{-\mathrm{ha}^{-1}}$ of hay having $15-16 \%$

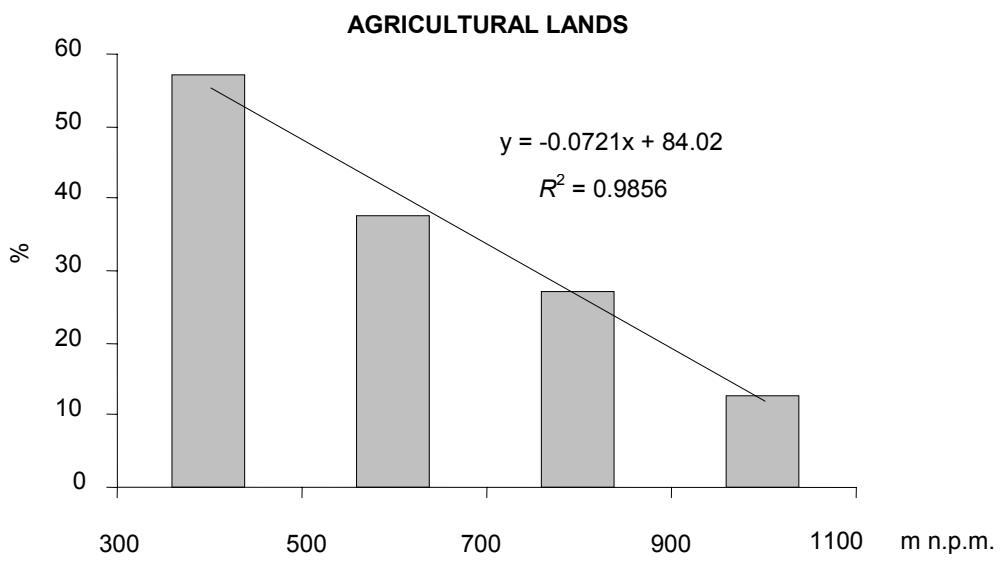

FORESTS

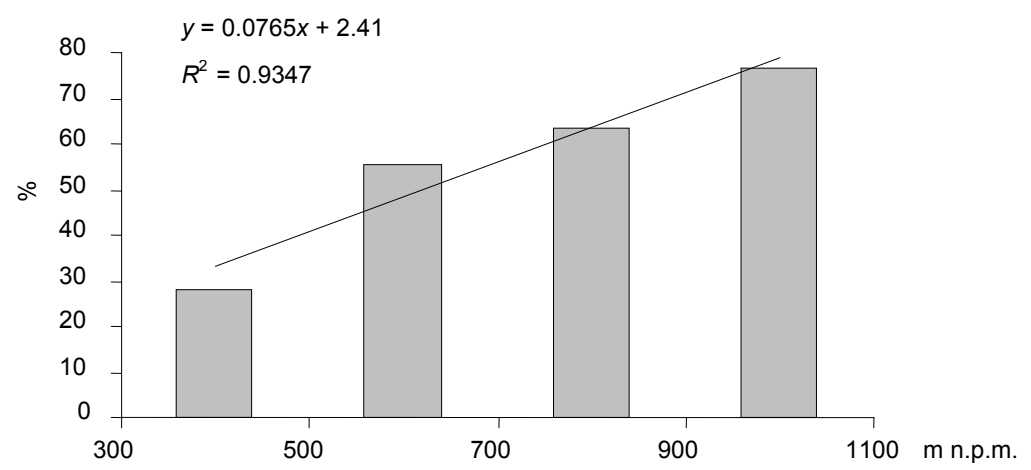

Fig. 5. Changes in the share of agricultural lands and forests in relation to elevation a.s.1. 
of water in its mass. Since this biomass production is obtained in low-cost agriculture, one may assume that it corresponds to the natural efficiency of local grasslands presented as curve no. 4 (Fig. 4).

Presented reduction of yielding in the years 1988-2008 which affected all zones of Carpathian agricultural lands between 300 and $1100 \mathrm{~m}$ a.s.l. resulted from gradual limitation or complete abandonment of grassland management. This in turn was an effect of general economic situation with respect to plant crops and animal production which discouraged farmers-highlanders from developing agricultural production.

Trend analysis suggests that structural changes of agricultural lands and forests with respect to elevation a.s.l. can be described with mathematical formulae as those presented in Fig. 5. They consider the status recorded in the first half of the first decade of the $21^{\text {st }}$ century (TWARDY, 2009). Observations showed that the changes of land use structure were less dynamic later on. Therefore, one may conclude of favourable spatial and structural stabilisation. In general, it consists in substantial increase of sward and forest cover with elevation a.s.l. and in marked decrease of the share of arable areas which in upper zones are usually present as small vegetable gardens.

\section{LAND USE CHANGES IN THE CARPATHIANS PRESENTED IN THE LITERATURE}

In the second half of the $20^{\text {th }}$ century scientists indicated that farming in the Carpathians is improperly managed. They based their observations on the results of many experimental studies. For example, KOSTUCH (1976) criticised an excessive agricultural exploitation of these areas and pointed to economically and environmentally irrational ploughing of slopes, particularly in higher mountain areas. He underlined risks associated with such practices and the disturbance of natural structural order by such cropping. He also petitioned for a comprehensive treatment of mountain areas i.e. not only as productive lands but also as water-bearing, recreational or natural medicine areas of additional landscape and aesthetic values. Many researchers underlined climatic dissimilarity, additionally modified by elevation above sea level, exposures and the so-called rain shadows (KUŹNIAR and TWARDY, 2001; OBRĘBSKA-STARKLOWA et al., 1995).

Land use structure of the Carpathian areas was analysed in details in the 1970s with the consideration of administrative division and elevation gradients (JAGŁA et al., 1981). At the same time, a complex proposal of structural changes within elevation zones and land use forms was presented together with economic and natural reasons for these changes. Later, similar structural data for the Carpathians were given by GUZIK (1995) but only for agricultural areas. Results of these studies were summarised in a synthesis of studies on grassland productivity in the moun- 
tains (KOSTUCH, TWARDY, 2004). Similar results were obtained by ZASTAWNY et al. (2001a; 2001b) and GŁĘBOCKI (2006), who analysed fodder resources from permanent grasslands in the years 1988-2002 and compared them with variable intensity of animal, particularly cattle and sheep, breeding. He found a significant reduction of farm animal stock at a large increase of the surface area of grasslands. As a result, there was an excess of fodder in relation to the number of ruminants and permanent grasslands were used extensively of were not used at all.

Recent structural analyses and studies on the amount of produced grass biomass show, however, that the trend of abandoning agricultural use of Carpathian lands has been reduced (TWARDY, 2009) partly due to areal subsidies and to subsidies for less favourable areas (LFA) (TWARDY, 2006; 2008).

One may assume, that now the better use of mountain areas will be associated with agro-environmental programmes and activities which prefer an increased share of grasslands in the structure of agricultural areas. Grasslands in turn will be used in a way more favourable for soil and aquatic habitats. Results of strict experimental studies tested under productive conditions should be helpful in such integrative approach. The studies involve both the technology of cropping arable lands (JUCHERSKI, 2008) and technical practices on meadows (KOSTUCH, 1976; KOSTUCH and TWARDY, 2004) with particular reference to the use of natural fertilisers (JANKOWSKA-HUFLEJT, 1998; 2001) as well as studies carried out in mountain areas and devoted to grazing and whole-season breeding of farm animals under various weather conditions (TWARDY, 1991). The latter pertain to novel solutions providing the improvement of quantitative and qualitative features of produced biomass and the hygienic way of production of sheep milk processed directly on pastures to obtain valuable soft (bundz) and hard (smoked) cheeses called oszczypek. Cited papers always contained ecological and nature protection aspects having in mind that future economic solutions should protect the natural environment and be economically verified.

As to the Carpathian areas, one should account for an increasing threat associated with the development of residential and recreation buildings, road infrastructure and tourist, sport, hotel and service investments. The risk is important since many administrative units do not have spatial management plans which is ruthlessly abused by developers (TWARDY, 2009). Therefore, one may expect shrinking of productive areas now used by agriculture.

\section{NON-PRODUCTIVE IMPORTANCE OF CARPATHIAN GRASSLANDS}

Agricultural management in the Carpathian areas is difficult or even very difficult and unreasonable from the economic point of view. At the same time, there is a strong social demand for low-cost agricultural activity which is associated not only with the protection of soil and aquatic habitats but also with the protection of 
species richness of plants and animals. There is also need for protecting soils, surface and ground waters and the whole habitats or unique landscape.

Universal, broadly understood protective functions are attributed to grasslands which successfully protect poor mountain soils from water and wind erosion. It is worth mentioning that both processes intensify with elevation and slope inclination. They are also stimulated by exposure (mainly westward) and arable crops (crop erosion) particularly if performed improperly with respect to slope lines (JUCHERSKI, 2008). Outwashing of soil material from unit area is determined by variable climatic factors. In the Carpathian areas they amount from 50 to 150 $\mathrm{m}^{3} \cdot \mathrm{km}^{-2}$ and decrease from the west to the east. The reverse relationship is observed for wind erosion which in eastern parts of the Polish Carpathians may exceed $200 \mathrm{~m}^{3} \cdot \mathrm{ha}^{-1}$ of agricultural soil (KOWALCZYK, 2007; STARKEL, 1972; TWARDY, 1993; TWARDY et al., 2004).

Plant cover, especially that forming dense sward, may largely mitigate the negative effects of natural factors like rainfall and wind power. Hence, many studies unambiguously indicate that grasslands should dominate in addition to forests in the Carpathian areas - meadows in the lower sites and pastures at higher elevations. The loss of soil material from so utilised areas is small (several dozen $\mathrm{kg} \mathrm{ha}^{-1}$ annually) while that from arable lands at the same slope may even reach several dozen tons. Moreover, dense cover of grass plants creates additional retention possibilities for the whole soil profile and is a kind of a filter intercepting and processing chemical substances from rainfall which was demonstrated in the long-term lysimetric studies (JAGUŚ and TWARDY, 2006). These abilities are, however, modified by the way and frequency of utilisation of meadow and pasture sward.

Grasslands play also an aesthetic function in the mountains. They make the landscape more attractive and improve local colour, especially when grazed by large herds of farm animals. There are also various cultural aspects transferred almost unchanged - as it is the case with common pasturage of mountain sheep from Mediaeval ages to the present days. This is undoubtedly a unique phenomenon in the European scale.

\section{SUMMARY}

Considering the data presented here, one may say that the present land use structure in the Carpathians is favourable. Present climatic and soil conditions prefer meadow and pasture management providing relatively high yields of grass biomass (KUŹNIAR and TWARDY, 2001). Permanent plant cover facilitates the development of low-cost and environmental friendly agriculture based on organic farms and agro-tourism. Moreover, such plant cover plays protective functions for soils and waters and an aesthetic role with respect to landscape and cultural values. 
It should be mentioned here that the Polish Carpathians are a refuge of biodiversity for plants and animals and for non-living natural values, for spatial systems of agriculture and forestry and for cultural landscapes. Therefore, the mountains are considered a specific area of unique environmental properties. These natural values were highly estimated in the Framework Convention of the protection and sustainable development of the Carpathians formulated in Kiev in 2003 and adopted in Poland in Dz. U. 96.634. The convention pertains to the whole Carpathian area and the accomplishment of its protective measures will require environmental friendly spatial planning, especially the sustainable and integrated water management, agriculture, forest management and tourism from the state authorities in the Carpathians territories.

Collected and presented here structural data allow for concluding that:

1. Structural changes taking place in the Carpathian areas during system transformation were deeper than in other regions of the country.

2. Agricultural and spatial restructuring of these areas is favourable and corresponds with sustainable and multi-functional development of rural areas.

3. The efficiency of agricultural production in the mountains is an output of many natural and economic factors. Therefore, the optimum and target solution is a low-input way of utilisation of meadows and pastures there.

4. Described areas are the spring grounds for many Carpathian rivers. The quality of their waters may be protected by the elimination of arable grounds in river valleys and their replacement by twice or thrice mown meadows.

5. Now, it is indispensable to optimise the relationships between agricultural and forest areas and the grounds under rural settlements and technical infrastructure to plan further directions of their development with the consideration of their sustainable and permanent use.

\section{REFERENCES}

1. GŁĘBOCKi B., 2006. Zasoby trwałych użytków zielonych a natężenie chowu bydła i owiec na obszarach górskich Polski w latach 1988-2002. (Permanent grassland resources and the intensity of cattle and sheep breeding in mountain areas of Poland in the years 1988-2002). Problemy Zagospodarowania Ziem Górskich, 53: 92-108.

2. GUZIK Cz., 1995. Rolnicze użytkowanie ziemi. W: Karpaty Polskie, przyroda, człowiek i jego działalność. (Agricultural land use. In: The Polish Carpathians, nature, humans and their activity). Ed. J. Warszyńska. Kraków, Wydaw. UJ: 239-242.

3. JAGUŚ A., TwARDY S., 2006. Wpływ zróżnicowanego użytkowania łąki górskiej na plonowanie runi i cechy jakościowe odpływających wód. (The effect of variable use of a mountain meadow on the yield of sward and qualitative features of outflowing waters). Falenty-Kraków, Wydaw. IMUZ: $1-88$.

4. JagŁa S., Kostuch R., Kurek S., PAwlik-Dobrowolski J., 1981. Analiza użytkowania ziemi w Karpatach na tle środowiska przyrodniczego. (Land use analysis in the Carpathians in relation to the natural environment). Problemy Zagospodarowania Ziem Górskich, 22: 39-65. 
5. JANKOWSKA-HufLEJT H., 1998. Nawozy organiczne pochodzenia zwierzęcego w renowacji i nawożeniu użytków zielonych - sposoby ich składowania i stosowania. W: Produkcja i wykorzystanie pasz z użytków zielonych w rolnictwie integrowanym na terenach górskich i podgórskich. (Organic fertilisers of animal origin in the restoration and fertilisation of grasslands - methods of their storage and use. In: Production and utilisation of grassland fodder in the integrated agriculture in mountain and sub-mountain areas). Mater. konf. ODR Nowy Sącz. Falenty, Wydaw. IMUZ: 41-50.

6. JanKowsKa-Huflejt H., 2001. Porównanie wpływu nawożenia mineralnego i obornikiem na trwałość gatunków oraz zmiany pH i zawartości substancji organicznej w glebie łąki trwałej. W: Trwała okrywa roślinna jako podstawa zrównoważonego rozwoju rolnictwa w zlewniach karpackich. (Comparing the effect of mineral and manure fertilisation on species persistence, $\mathrm{pH}$ changes and the content of organic matter in soil of permanent meadow. In: Permanent plant cover as a basis for sustainable development of agriculture in the Carpathian catchments). Konf. Jaworki 9-11 października 2001. Falenty, Wydaw. IMUZ: 197-204.

7. JuCHERSKI A., 2008. Problemy rozwoju górskiej techniki rolniczej. (Problems of the development of mountain agricultural technique). Warszawa, IBMER: 1-153.

8. Kostuch R., 1976. Przyrodnicze podstawy gospodarki łąkowo-pastwiskowej w górach. (Biological foundations of grassland management in the mountains). Warszawa, PWRiL: 1-151.

9. Kostuch R., Twardy S., 2004. Badania produkcyjności użytków zielonych w Karpatach Polskich. (Studies on grassland productivity in the Polish Carpathians). Woda Srodowisko Obszary Wiejskie, 4, 1 (10): 247-258.

10. KowAlCZYK A., 2007. Obliczenia wielkości erozji wodnej gleb na obszarach górskich. (Calculating water erosion of soils in mountain areas). Woda Środowisko Obszary Wiejskie, 7, 1 (19): 91-103.

11. KuŹNIAR A., TWARDY S., 2001. Warunki przyrodniczo-gospodarcze Karpat Polskich z uwzględnieniem niedoborów wodnych. W: Niskonakładowa produkcja rolnicza z wykorzystaniem pasz z użytków zielonych w Karpatach Polskich. (Natural and economic conditions in the Polish Carpathians with the consideration of water deficits. In: Low-input agriculture production with use of forages from grassland in the Polish Carpathians). Eds H. Jankowska-Huflejt, J. Zastawny. Falenty, Wydaw. IMUZ: 33-45.

12. Obręiska-Starklowa B., Hess M., Olecki Z., TrepińsKa J., Kowanetz L., 1995. Klimat. W: Karpaty Polskie, przyroda, człowiek i jego działalność. (Climate. In: The Polish Carpathians, nature, humans and their activity). Ed. J. Warszyńska. Kraków, Wydaw. UJ: 31-47.

13. StARKel L., 1972. Charakterystyka rzeźby Polskich Karpat (i jej znaczenie dla gospodarki ludzkiej). (The characteristics of the Polish Carpathians relief (and its importance for human economy)). Problemy Zagospodarowania Ziem Górskich, 10: 75-91.

14. TWARDY S., 1991. Organizacja wielkostadnej gospodarki pasterskiej w górach przy uwzględnieniu mechanicznego dojenia owiec. (Organisation of large pastoral economy in the mountains with the consideration of mechanical sheep milking). Kraków-Falenty, Wydaw. IMUZ: 1-84.

15. TWARDY S., 1993. Warunki przyrodnicze a użytkowanie ziemi w Karpatach. (Natural conditions and land use in the Carpathians). Postępy Nauk Rolniczych, 3: 51-60.

16. TWARDY S., 2006. Zasady dofinansowania rolnictwa na obszarze Karpat. (Principles of financing agriculture in the Carpathian areas). Wiadomości Melioracyjne, 3 (410): 129-133.

17. TWARDY S., 2008. Karpackie użytki rolne jako obszary o niekorzystnych warunkach gospodarowania (ONW). (Carpathian agricultural lands as less favourable areas (LFA)). Woda Środowisko Obszary Wiejskie, 8, 2b (24): 191-202.

18. TWARDY S., 2009. Tendencje zmian w użytkowaniu przestrzeni rolniczej obszarów karpackich. (Tendencies of changes in the use of agricultural space in the Carpathian areas). Studia i Raporty IUNG - PIB, 17: 49-58.

19. Twardy S., KopaCz M., Lipski Cz., 2004. Wpływ okrywy darniowo-leśnej na stosunki hydrologiczne i wynoszenie materiału skalnego w wodach potoków górskich. W: Czynniki wpływające na erozję mechaniczną i chemiczną oraz depozycję materiału dennego w korytach 
na erozję mechaniczną i chemiczną oraz depozycję materiału dennego w korytach rzecznych wybranych zlewni górskich w Karpatach Zachodnich. (The effect of grass and forest cover on hydrologic conditions and rocky debris transport in mountain streams. In: Factors affecting mechanical and chemical erosion and deposition of bottom material in river channels of selected mountain catchments in the Western Carpathians). Ed. Cz. Lipski. Kraków, Wydaw. AR: 79-98.

20. Zastawny J., Moraczewski R., Jankowska-Huflejt H., 2001a. Spadek pogłowia bydła i owiec na tle niewykorzystanego potencjału górskich i podgórskich trwałych użytków zielonych jako skutek transformacji ustrojowej w Polsce. (A decrease of cattle and sheep livestock in relation to unused potential of mountain and sub-mountain permanent grasslands - an effect of system transformation in Poland). Wiadomości Melioracyjne i Łąkarskie, 4: 196-198.

21. Zastawny J., Moraczewski R., Jankowska-Huflejt-H., 2001b. Analiza stanu wykorzystania trwałych użytków zielonych w rejonach górskich i podgórskich na tle rozwoju rolnictwa w kraju. W: Niskonakładowe systemy produkcji rolniczej w warunkach górskich użytków zielonych Karpat Polskich. (An analysis of permanent grassland utilisation in mountain and sub-mountain regions in relation to agricultural development in the country. In: Low-input systems of agricultural production of mountain grasslands in the Polish Carpathians). Eds J. Zastawny, H. Jankowska-Huflejt. Falenty, Wydaw. IMUZ: 57-64.

\section{STRESZCZENIE}

\section{Rola użytków zielonych w procesie tworzenia ladu strukturalno-przestrzennego obszarów wiejskich}

Słowa kluczowe: górskie obszary wiejskie, trwate użytki zielone, zmiany strukturalne

W Polsce struktura użytkowania ziemi zaczęła się wyraźniej zmieniać pod koniec lat 80. minionego wieku. Związane było to $\mathrm{z}$ transformacją ustrojową. Przeobrażenia dotyczyły zarówno użytków rolnych, których areał wydatnie się zmniejszył, jak i obszarów leśnych, stopniowo z kolei powiększających swoją powierzchnię. Zwiększały się również obszary zajmowane pod zabudowę i infrastrukturę. Omawiane zmiany dotknęły również obszary górzyste, w tym karpackie, co w niniejszej pracy zobrazowano w odniesieniu do lat 1988-2008 oraz różnych stref ich wysokości. Następstwem ich były istotne zmiany w obrębie obszarów wykorzystywanych rolniczo. W strukturze użytków rolnych Karpat Polskich grunty orne zmniejszyły swój udział o ok. 40\%, a użytki zielone zwiększyły o ponad $70 \%$ w porównaniu ze stanem sprzed transformacji ustrojowej. Równocześnie znacznie też zwiększył się udział obszarów pozostałych, w tym nieużytków.

Wraz ze wzrostem wysokości n.p.m. ubywa gruntów ornych, a zwiększa się obszar łąk i pastwisk. Obecnie w przedziale hipsometrycznym 700-1100 m n.p.m. grunty orne zajmują 5,6-16,3\%, a użytki zielone $65,4-68,7 \%$ ogólnej powierzchni użytków rolnych. Pozostałe, głównie nieużytki, utrzymują się w granicach 18,3$25,7 \%$. W obszarach górskich użytki zielone spełniają obok funkcji produkcyjnych również funkcje ochronne. Dlatego też ogranicza się tu intensywność ich użytko- 
wania, co wpływa ujemnie na ilość uzyskiwanej biomasy. Zmienność wytwarzanej biomasy w czasie i przestrzeni przedstawiono graficznie na przykładzie plonowania trwałych użytków zielonych. W latach 1988-1992 oceniano ją średnio na 6,8 tha, a w latach 2007-2008 już tylko na 5,6 tha siana łąkowego. Przyczyną tak wyraźnego zmniejszenia plonowania było zdecydowanie mniejsze zainteresowanie rolników (górali) chowem i hodowlą przeżuwaczy. Obecnie w górach występuje nadprodukcja biomasy trawiastej $\mathrm{w}$ stosunku do możliwości jej wykorzystania przez zwierzęta.

Opisane przeobrażenia sa jednak korzystne dla środowiska. Trwałe zadarnienie chroni ubogie i płytkie gleby górskie przed procesami erozyjnymi - erozją wodną i wietrzną. Podobną rolę spełniają również lasy, których udział wraz ze wzniesieniem nad poziom morza wyraźnie się zwiększa. Restrukturyzacja rolnoprzestrzenna omawianych obszarów była zatem korzystna i korespondowała z dążnością do zrównoważonego i wielofunkcyjnego rozwoju obszarów wiejskich położonych w górach. 